\title{
Pengembangan Perangkat Pembelajaran Model PBL Berbasis STEM untuk Melatih Keterampilan Berfikir Kreatif Siswa Tuna Netra
}

\author{
Fitria Sarnita $^{1, *}$, Ainun Fitriani ${ }^{2}$, Widia $^{3}$. \\ ${ }^{1,2}$ STKIP Taman Siswa \\ ${ }^{3}$ MA Alfalah \\ ${ }^{1}$ fitriasarnitha@yahoo.co.id, ${ }^{2}$ ainunfitriani@gmail.com, ${ }^{3}$ widia.fisika09@gmail.com \\ ${ }^{*}$ Coresponding Author.
}

Artikel Info

Tanggal Publikasi

2019-06-30

Kata Kunci

LKS

STEM

Keterampilan berfikir Kreatif Siswa

\section{Abstrak}

Tujuan penelitian ini adalah untuk mengembangkan perangkat pembelajaran berbasis STEM dan mempermudah guru dalam menyampaikan materi dan memberikan pemahaman sekaligus melatih keterampilan berikir kreatif siswa tuna netra. Selain dari itu mempermudah guru dalam menyampaikan materi yang abstrak kepada siswa tuna netra. Penelitian ini menggunakan penelitian $\mathrm{R}$ \&D (Research and Development). Instrumen yang diguakan dalam penelitian ini adalah Lembar keterlaksanaan RPP, Lembar Pegamatan Aktivitas Siswa, Lembar Respon siswa, Soal berfikir Kreatif siswa tuna netra. Hasil Analisis Validasi validasi RPP berada pada skala 3,307 dengan kategori valid, LKS berada pada skala 3,5 dengan kategori valid, lembar pengamatan aktivitas siswa berada pada skala 3,3 dengan kategori valid, lembar respon siswa berada pada skala 3,5 dengan kategori valid, sedangkan untuk soal berpikir kreatif berada pada skala 3,6 dengan kategori sangat valid.

\section{PENDAHULUAN}

Belajar merupakan suatu keharusan bagi siswa, terutama siswa tuna netra. Anak tunanetra adalah individu yang indera penglihatannya (kedua-duanya) tidak berfungsi sebagai saluran penerima informasi dalam kegiatan sehari-hari seperti halnya orang normal (Sarnita F dan Andy Eddy, 2018). Menurut Hikmah N.F, Pramudya Yudhiakto (2014) tuna netra atau siswa yang memiliki kebutuhan khusus memiliki hak yang sama seperti siswa normal lainnya untuk belajar. Belajar haruslah memberikan perubahan perilaku positif bagi siswa. Menurut Muhammad Ali (2004) Belajar adalah suatu perubahan perilaku, akibat interaksi dengan lingkungannya. Dengan demikian belajar dikatakan berhasil apabila terjadi perubahan dalam diri individu (Satriawan M., Murtalib \& Widia, 2018.a). Maka dipandang perlu untung merancang pembelajaran yang dapat membantu siswa dalam belajar, mengoptimalkan segala potensi yang ada pada dirinya. Sehingga dengan keterbatasan yang mereka miliki tidak membuat mereka terbelakang.

Berdasarkan hasil observasi peneliti di SLB Baiturrahman terdapat kesulitan bagi guru untuk menyampaikan materi terutama pada mata pelajaran IPA materi Tata surya yang yang bersifat abstrak, karena lembar kegiatan siswa (LKS) yang tersedia terbatas pada ranah kognitif saja. Seharusnya siswa dengan keterbatasan tertentu (tuna netra) haruslah dilatih keterampilan-keterampilan tertentu sebagai penunjang keterbatasan yang ada dalam dirinya, salah satunya adalah keterampilan berpikir kreatif. Berpikir kreatif merupakan bagian terpenting diera revolusi idustri 4.0. maka keterampilan berpikir kreatif harus dilatih sedini mungkin, apalagi di tingkat menengah atas (SMA) sehingga mereka bisa bersaing didunia industri dan masyarakat. Karena dari sinilah karakter mereka mulai terbentuk dan menjadi bagian terpenting dalam sejarah hidup mereka (Satriawan M., Murtalib \& Widia, 2018.b). Ada empat karakter berpikir kreatif menurut Torrance (dalam Dennis K. F, 2008), yakni (1) 
Originality yakni keunikan dari ide yang diungkapkan; (2) Fluency yakni kemampuan untuk menciptakan ide sebanyakbanyaknya; (3) Flexibility yakni kelenturan dalam berpikir, Ini ditunjukkan dengan tidak adanya ide yang sama saat seseorang diminta mengungkapkan ide atau pendapatnya; (4) Elaboration ditunjukkan oleh sejumlah tambahan dan detail pada setiap ide sehingga stimulus sederhana menjadi lebih kompleks.

Untuk mengatasi kesulitan yang dihadapi oleh guru dan untuk mempersiapkan siswa tuna netra mampu mengambil bagian penting diera rovolusi industri 4.0. Maka peneliti mengembangkan LKS berbasis STEM dengan Prototype Benda Langit. Penelitian ini menyusun Prototype Benda Langit berupa sembilan Planet terdiri dari Merkurius, Venus, Mars, Bumi, Saturmus, Uranus, Neptunus dan Pluto. LKS adalah salah satu bahan ajar yang memainkan peran penting dalam memastikan efektivitas kegiatan belajar mengajar (Kaymakci, 2012). Sedangkan STEM merupakan suatu pendekatan pengajaran dan pembelajaran antara dua atau lebih dalam komponen STEM atau antara satu komponen STEM dengan disiplin ilmu lain (Becker \& Park, 2011). Pengintegrasian pendidikan STEM dalam pengajaran dan pembelajaran boleh dijalankan pada semua tingkatan pendidikan, mulai dari sekolah dasar sampai universitas, karena aspek pelaksanaan STEM seperti kecerdasan, kreatifitas, dan kemampuan desain tidak tergantung kepada usia (Sanders et al, 2011). Ide penelitian ini bertujuan untuk mempermudah guru dalam menyampaikan materi dan memberikan pemahaman sekaligus melatih keterampilan berikir kreatif siswa tuna netra. Selain dari itu mempermudah guru dalam menyampaikan materi yang abstrak kepada siswa tuna netra.

\section{METODE PENELITIAN}

Penelitian ini menggunakan penelitian R \&D (Research and Development). Penelitian R \& D digunakan untuk mendesain produk atau prosedur yang teruji secara sistematis di lapangan, dievaluasi dan dikembangkan sedemikian rupa sehingga memenuhi kriteria efektivitas, kualitas atau kemiripan dengan suatu standar (Gall et al, 2003). Pengembangan yang dilakukan adalah pengembangan LKS beerbasis STEM untuk melatih keterampilan berfikir siswa tuna netra. Populasi dalam penelitian ini adalah Sekolah Luar Biasa (SLB) Se-kabupaten Bima, dengan Sampel penelitian SLB Baiturrahman Bima.

\section{Rancangan Penelitian}

Tahapan perancangan pada pengembangan $R \& D$ :

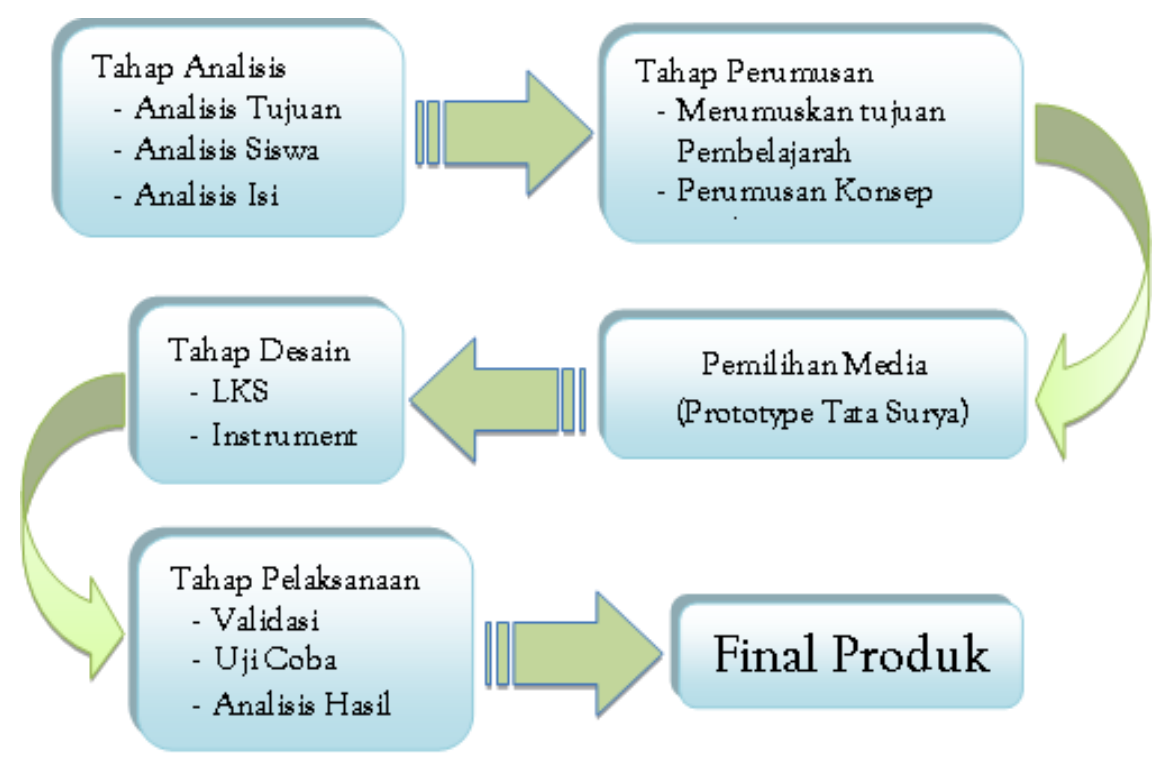

Gambar 1. Diagram Pengembangan Perangkat R\&D. 


\section{Instrumen Penelitian}

- Lembar keterlaksanaan RPP

- Lembar Pengamatan Aktivitas Siswa

- Lembar Respon Siswa

- Soal Berpikir Kreatif

\section{Teknik Pengumpulan Data}

- Wawancara

- Observasi

- Angket

- Unjuk Kerja dan Tes Uraian

\section{Teknik Analisis Data}

Analisis Keterlaksanaan RPP

Pengamatan keterlaksanaan pembelajaran diisi oleh dua orang pengamat pada saat proses pembelajaran berlangsung dengan menggunakan empat skala penilaian yaitu skala 1 "tidak baik". Skala 2 "kurang baik". Skala 3 "baik". Skala 4 "sangat baik" (Kemendikbud, 2013). Persentasi tingkat kecocokkan (Percentage of Agreement) antara pengamat leterlaksanaan RPP dihitung dengan rumus berikut:

Ket :

$$
\text { Percentage of Agreement }(R)=\left(1-\frac{A-B}{A+B}\right) \times 100 \% \ldots(1)
$$

A $=$ Frekuensi nilai tertinggi yang diberikan oleh pengamat.

$\mathrm{B}=$ Frekuensi nilai terrendah yang diberikan oleh pengamat.

Persentase keterlaksanaan RPP dikatakan BAIK jika $\geq 0,75 \%$ Borich (dalam Mujakir, 2016) Analisis Pengamatan Aktivitas Siswa.

Lembar pengamatan disisi oleh pengamat dengan cara memberikan check list. skala 1 "tidak baik". Skala 2 "kurang baik". Skala 3 "baik" (Kemendikbud, 2013). Perhitungan kecocokan penilaian antaran pengamat dihitung dengan menggunakan rumus:

Ket :

$$
\text { Percentage of Agreement }(R)=\left(1-\frac{A-B}{A+B}\right) \times 100 \%
$$

$\mathrm{A}=$ Frekuensi nilai tertinggi yang diberikan oleh pengamat.

$\mathrm{B}=$ Frekuensi nilai terrendah yang diberikan oleh pengamat.

Persentase aktivitas siswa dikatakan BAIK jika $\geq 0,75 \%$ Borich (dalam Mujakir, 2016).

Analisi Respon Siswa.

Pengamatan respon siswa diisi oleh siswa yang bersangkutan dengan cara memberikan check list. Data selanjutnya dianalisis menggunakan rumus (Arifah, 2012) :

Ket :

$$
P=\frac{\Sigma K}{\Sigma N} \times 100 \%
$$

$\mathrm{P} \quad=$ Peresentase Respon Siswa

$\sum \mathrm{K}=$ Jumlah Siswa yang merespon

$\sum \mathrm{N} \quad=$ Jumlah total siswa

Analisis Keterampilan Berfikir Siswa. 
Tes berpikir kreatif siswa bertujuan untuk mengukur unsur-unsur berpikir kreatif siswa pada materi yang diajarkan. Karena siswa yang menjadi obyek penilaian adalah siswa tuna netra, maka tes ini berbentuk daftar periksa (Cheklist) dan Kuisioner; alat ini disusun berdasarkan penelitian tentang karakteristik khusus yang dimiliki pribadi kreatif.

Tabel 1. Kriteria Berpikir Kreatif Siswa

\begin{tabular}{cc}
\hline Interval Skor rata-rata & Kategori \\
\hline $81,00 \%-100 \%$ & Sangat Kreatif \\
$65,00 \%-80,99 \%$ & Kreatif \\
$41,00 \%-64,99 \%$ & Kurang Kreatif \\
$0,00 \%-40,99 \%$ & Tidak Kreatif \\
\hline
\end{tabular}

\section{HASIL DAN PEMBAHASAN}

Validitas

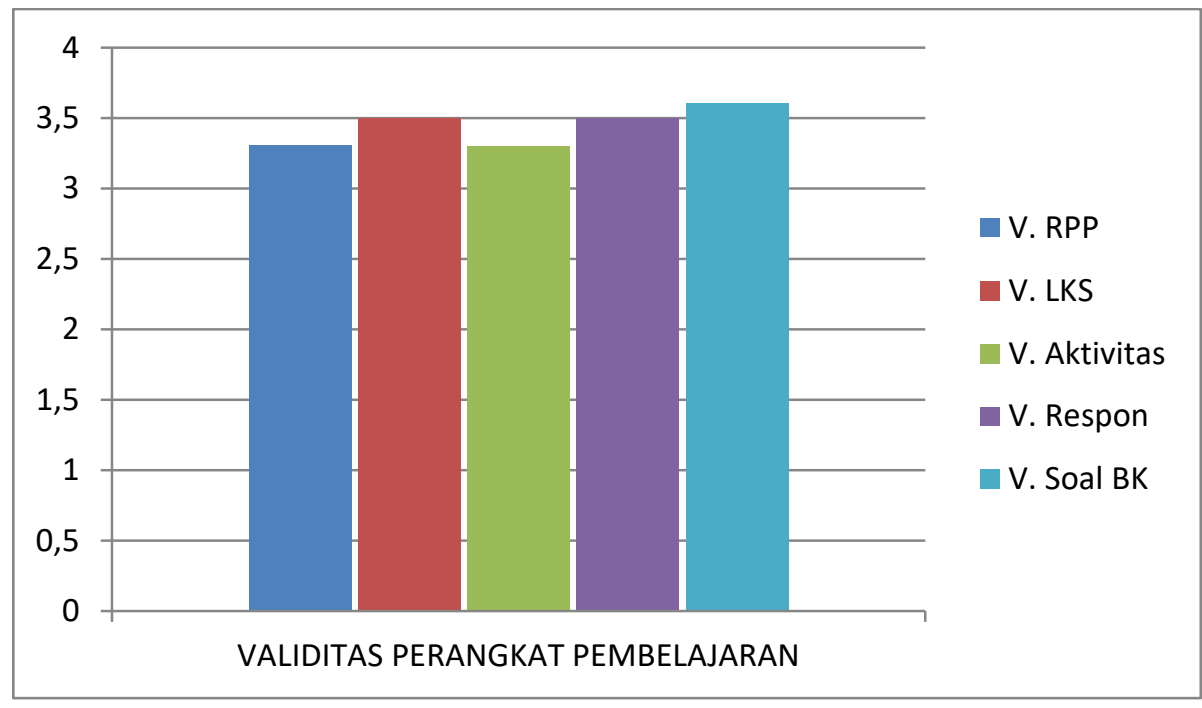

Grafik 1. Validasi Lembar Kerja Siswa.

Hasil validasi berupa telaah, penilaian, dan saran dari validator, nilai validasi RPP berada pada skala 3,307 dengan kategori valid, LKS berada pada skala 3,5 dengan kategori valid, lembar pengamatan aktivitas siswa berada pada skala 3,3 dengan kategori valid, lembar respon siswa berada pada skala 3,5 dengan kategori valid, sedangkan untuk soal berpikir kreatif berada pada skala 3,6 dengan kategori sangat valid. RPP, LKS, Instrum dan jenis perangkat pembelajaran lainnya baru bisa digunakan jika persentase kecocokan antara validator $\geq 75$ \% (Borich, 1994). Persentase kecocokan dari masing-masing perangkat yang telah dibuat rata-rata $\geq 75 \%$. Sedangkan Percentage Of Agreement (R) atau persentasi kecocokan kedua validator untuk RPP adalah 98,81. LKS adalah 93,7. Lembar aktivitas siswa adalah 89,87 . Lembar respon siswa adalah 91,37. Sedangkan untuk soal berpikir kreatif siswa adalah 97,56. Artinya perangkat pembelajaran yang dikembangkan bisa digunakan untuk dilakukan uji coba pada siswa.

\section{Kepraktisan}

Perangkat pembelajaran yang dikembangkan dikatakan praktis apabila RPP terlaksana dengan baik tanpa ada hambatan serta mendukung aktivitas siswa sesuai dengan tujuan pembelajaran yaitu melatih siswa berpikir kreatif menggunakan PBL berbasis STEM. Pengamatan dilakukan selama 3 kali pertemuan oleh dua orang pengamat, hasil analisis dari semua kegiatan yang ada di dalam RPP dengan skor rata-rata adalah 3,62 dengan kategori sangat baik. Dapat dihat pada grafik 2. 


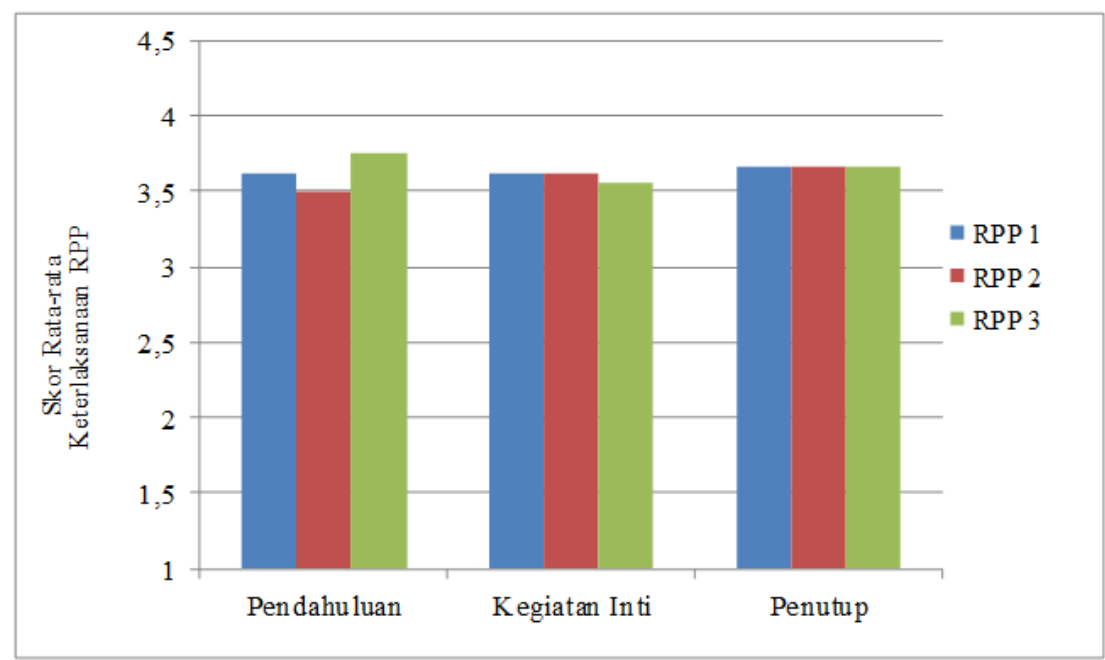

Grafik 2. Keterlaksanaan Rencana Proses Pembelajaran.

Sedangkan hasil pengamatan untuk aktivitas siswa dapat diketahu dari pertemuan perama sampai pertemuan ke-3. Hal ini terbukti dari peningkatan aktivitas siswa yang signifikan dari pertemuan pertama sampai pertemua terakhir. Pada pertemuan pertama hanya $60 \%$ siswa yang aktif dan memberikan kontribusi positif, namun diakhir pertemua meningkat menjadi $90 \%$ siswa. Keterlibatan siswa secara aktif dalam pembelajaran membuatnya terlatih menemukan alternatif lain dalam menyelesaikan masalah yang ditemukan dalam pembelajaran. Hal ini senada dengan Vygotsky (dalam Arends 2012) kecerdasan berkembang karena orang menghadapi pengalaman-pengalaman baru dan membinggungkan kemudian berusaha menyelesaikan perbedaan dengan mengkaitkan pengetahuan baru dengan pengetahuan awal dan membangun makna baru.

\section{Keefektifan}

Perangkat pembelajaran yang dikembangkan dikatakan efektif apabila instrumen atau soal yang dibuat dapat mengukur apa yang diukur dan siswa memberikan respon positif terhadap model, metode, strategi atau prangkat yang telah kita kembangkan. Hasil analisis peningkatan keterampilan berpikir kreatif rata-rata seluruh siswa setelah mengikuti pembelajaran selama tiga pertemuan pada aspek berpikir kreatif sebelum perlakuan sebesar 58,83\% dengan kategori kurang kreatif. Sedangkan setelah diberikan perlakuan meningkat menjadi 80,2\% dengan kategori kreatif.

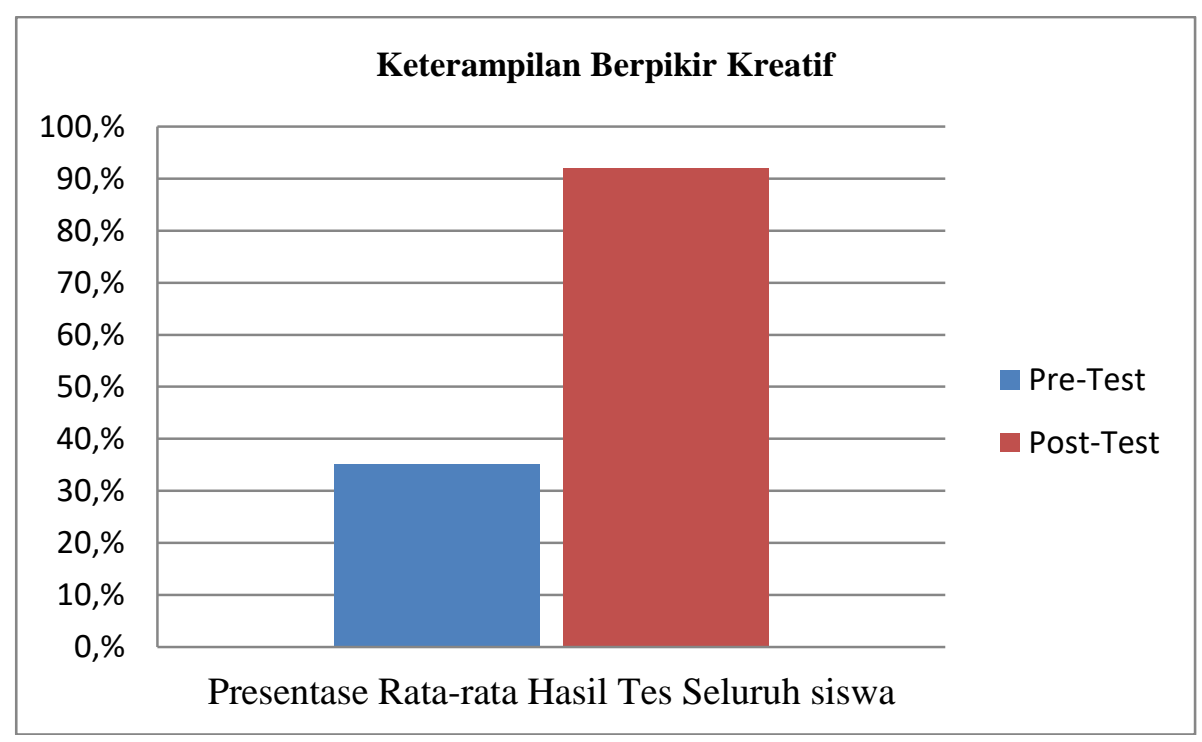

Grafik 3. Peningkatan Hasil Tes Berpikir Kreatif Siswa.

Perangkat pembelajaran yang telah dikembangkan bertujuan untuk memberikan kontribusi kepada peningkatan berpikir kreatif siswa. Seperti pada LKS yang telah dirancang berbasis STEM 
memberikan ruang kepada siswa untuk melakukan percobaan, terlibat secara aktif dalam proses belajar, menyampaikan ide sebanyak mungkin, mencoba sesuatu yang baru. Nur M., (2014) menjelaskan bahwa satu-satunya cara agar orang dapat mempelajari teknik-teknik dalam melakukan penemuan adalah ia memiliki kesempatan untuk melakukan penemuan. Tes berpikir kreatif ini bertujuan untuk mengetahui sejauh mana tingkatan berpikir kreatif yang dimiliki oleh siswa, karena tidak ada jaminan bahwa siswa yang pintar bisa dikatakan siswa yang kreatif. Esensi dari tes keterampilan berpikir kreatif adalah untuk melatih bagaimana keluasan dan imajinasi orang dalam menganalisi masalah (Adams, 2005).

Sehingga diharapkan ketika siswa mampu menyelesaikan masalah di sekolah dengan unsurunsur kreatif, maka siswa tersebut juga dapat menyelesaikan masalah dalam kehidupannya sehari-hari. Sedangkan hasil analisis respon siswa selama proses pembelajaran dan pada perangkat yang dikembangkan diperoleh rata-rata siswa merespon positif terhadap kriteria-kriteria yang diajukan. Sebanyak 100\% dari seluruh responden merasa tertarik terhadap model pembelajaran dan perangkat yang gunakan, dan berharap supaya pada kegiatan pembelajaran berikutnya seperti yang mereka terima dapat diterapkan kembali.

\section{KESIMPULAN}

Didasarkan pada temuan-temuan, hasil penelitian dan pembahasan dapat disimpulkan bahwa penerapan LKS berbasis STEM yang dikembangkan layak untuk melatihkan keterampilan berpikir kreatif siswa.

\section{Daftar Pustaka}

Adams K. (2005) The Sources of Innovation and Creativity. National Center on Education and the Economy (NCEE)

Arends, R. I. (2012). Learning to Teach: Belajar untuk mengajar edisi Ketujuh Buku Satu. Yogyakarta: Pustaka Pelajar

Arifah Purnamaningrum dkk, 2012. Peningkatan Kemampuan Berpikir Kreatif Melalui Problem Based Learning (PBL) Pada Pembelajaran Biologi Siswa Kelas X-10 SMA Negeri 3 Surakarta Tahun Pelajaran 2011/2012. Pendidikan Biologi Vol. 4, No. 3, hal 39-51.

Becker, K., \& Park, K. 2011. Effects of integrative approaches among science, technology, engineering, and mathematics (STEM) subjects on students' learning: A preliminary meta analysis. Journal of STEM Education: Innovations and Research, 12(5/6), 23.

Borich, Gray D. (1994). Observation Skill for Effective Teaching. New York:Macmillan Publishing Company

Dennis, K. \& Filasaime, (2008). Menguak Rahasia bepikir Kritis dan Kreatif. Jakarta; Prestasi Pustakaraya.

Fitria Sarnita \& Andy Eddy (2018). Prototype Benda Langit Siswa Tuna Netra Dalam membentuk Pemahaman Konsep Materi Tata Surya. Bima. Jurnal Gravity Edu 2(1). 25. https://doi.org/10.33627/ge.v2i2.153.

Gall, M.D., Gall, J.P., \& Borg, W.R., Educational Research an Education Seventh Edition, Pearson Education, Inc, 2003.

Kaymakci, S. 2012. A Review of Studies on Worksheets in Turkey. US-China Education Review A 1. 57-64.

Kemendikbud.(2013). Kurikulum 2013. Jakarta: Badan Penelitian dan Pengembangan. 
Khanafiyah, S \& Rusilowati, A. (2010). Penerapan Pendekatan Modified Free Inquiry sebagai Upaya Meningkatkan Kreativitas Mahasiswa Calon Guru dalam Mengembangkan Jenis Eksperimen dan Pemahaman Terhadap Materi Fisika. Jurnal Berkala Pendidikan, Universitas Negeri Semarang.Vol. 13. No. 2, pp 7-17.

Nur, M. (2014). Berpikir Kreatif. Surabaya: Penelitian Unggulan Perguruan Tinggi UNESA.

Mujakir. (2016). Strategi Pembelajaran Berdasarkan Multi Level Representasi untuk Meningkatkan Kemampuan Memecahkan Masalah Kimia Bagi Mahasiswa Calon Guru. Disertasi_tidak dipuplikasikan. Surabaya: Pasca Sarjana Unesa.

Sanders, M., Hyuksoo. K., Kyungsuk, P. \& Hyonyong, L. 2011. Integrative STEM (Science, Technology, Engineering, and Mathematics) Education: Contemporary Trends and Issues. Secondary Education 59, 729-762.

Satriawan. M., Murtalib \& Widia (2018.a) Pengambangan Perangkat Model Problem Based Learning (PBL) untuk Meningkatkan Hasil Belajar Siswa SMAN 1 Ambalawi. Prosiding Seminar Nasional 29 September 2018. Mataram: Lembaga Penelitian dan Pendidikan (LPP) Mandala. (2018.b) Pengembangan Perangkat Pembelajaran Fisika Model Problem Based Learning (PBL) Berbasis Karakter Maja Labo Dahu untuk Melatih Keterampilan Berpikir Kreatif Siswa. Jurnal Pembelajaran dan Pengajaran Fisika (Gravity Edu). Vol. 1, No. 2. hal. 220-224. 